\title{
Unemployment and Protest in the United States, 1890-1940: A Methodological Critique and Research Note*
}

\author{
H A R O L D R. K E R B O, California Polytechnic State \\ University, San Luis Obispo \\ R I C H A R D A. S H A F F E R, California Polytechnic State \\ University, San Luis Obispo
}

\begin{abstract}
We begin with a critique of previous methods (event analysis) employed in testing deprivation theories of social movements and collective violence. Then we consider the value of group analysis through examination of the relationship between one form of deprivation (unemployment) and collective action by the unemployed in the United States from 1890-1940. By using group analysis we are able to discover that the relationship between unemployment and collective action varied considerably between 1890 and 1940, suggesting that other variables often stressed by those rejecting deprivation theories are needed for fully understanding the subject.
\end{abstract}

In direct contrast to older deprivation theories of social movements and political violence is resource mobilizatin theory (Kerbo; McCarthy and Zald). Rather than a focus on deprivation as a motivating factor for social movement activity, resource mobilization theory sees an increase in resources such as time, money, the freedom to organize, or outside material and/or political support as the primary factor producing new social movement activity. Though resource mobilization theories have come to dominate the study of social movements, the debate over the extent to which deprivation theories are useful continues. Since Snyder and Tilly's oftencited empirical rejection of deprivation theories, however, most works

*An earlier version of this paper was presented at the 1983 Southwestern Social Science Association meetings. We are grateful to Roxy Peck, Bob Smidt, and Alden Shiers for providing assistance in the analysis of the data. The original data collection was funded by a CARE Grant from California Polytechnic State University, San Luis Obispo. Address correspondence to Harold Kerbo, Social Sciences Department, California Polytechnic State University, San Luis Obispo, CA 93407. 
continuing to employ deprivation theories in some form have been case studies (e.g., Carroll; Champagne; Isaac et al.; Page and Clelland; Thornton; Useem; Walsh and Warland). The broad empirical studies of the Snyder and Tilly variety (see Paige; Tilly et al.) have been unable to show any support for deprivation theories.

In this paper we address one basic question: Have these broad empirical studies employed a proper method for testing the explanatory power of resource mobilization and deprivation theories? We begin with a methodological critique of "event analysis," then examine the relationship between unemployment and protest by the unemployed in the United States between 1890 and 1940 to show the value of another methodological approach we call "group analysis."

\section{Event Analysis vs. Group Analysis}

In event analysis a researcher collects information on all recorded events of political violence in a specified time period, no matter what group has committed the violent acts. Then, using some form of time series analysis the researcher matches independent variables such as indicators of hardship to the events of political violence. In other words, the focus is on all events of political violence, not on particular groups of people who may have been prone to political violence for some reason. For example, Snyder and Tilly used three measures of hardship: (1) food prices, (2) prices of manufactured goods, and (3) industrial production in France from 1830 to 1960. The dependent variable in their research was collective violence in the same period, defined as "continuous interactions involving at least one group of fifty or more persons in the course of which someone seized or damaged persons or objects over resistance" (522). They then employed regression analysis to show that the three indicators of economic hardship were not significantly related to their measures of collective violence. Such a method, however, requires some questionable assumptions.

First, if we are to accept this method it must be assumed that religious, racial, political, and other types of conflicts do not result in significant levels of collective violence. It is important to stress that these studies measure all cases of collective violence irrespective of the issues involved. But if noneconomic issues and conflicts also produce significant levels of collective violence, then any relationship between economic hardship and collective violence may remain undetected using event analysis. For example, let us assume there are 20 time periods with significant levels of collective violence. Let us assume that in 5 of these time periods religious conflicts are the driving force behind most collective violence, that in 5 periods violence involves racial conflict, that in 5 it involves conflicts over old political rights, and that in 5 it involves economic hardship (such as 
unemployment). And let us further assume that during most of the religious, racial, and political conflicts, economic conditions were average to good. With this example we are sure to find no statistical relationship between collective violence (of all kinds) and indicators of economic hardship using event analysis.

Second, if we are to accept event analysis it must be assumed that no types of collective violence are more likely in better economic times. If this assumption is not correct, and all types of collective violence are measured, then the collective violence occurring in better economic times may cancel any relationship between economic hardship and collective violence. There is, in fact, research indicating that industrial conflict is more likely in better economic times (Hibbs,a; Shorter and Tilly; Skeels; Snyder).

Following our criticisms of event analysis, we have chosen what we believe is a method of analysis more suitable for detecting any relationship between economic hardship and protest. We focus on unemployment as one form of economic hardship, and examine the response of the unemployed in the United States from 1890 to 1940 . Thus, we are not concerned with protest or collective violence related to other issues or initiated by groups other than the unemployed. ${ }^{1}$ Our goal is to discover whether a specific form of economic hardship (unemployment) is consistently related to protest by those most affected by this economic hardship (the unemployed). Thus, we are using group analysis by following a category of people through time to examine what factors seem to influence their involvement in social movement activity.

\section{Data and Methods}

The primary independent variables in our analysis are related to unemployment. Our measures of the percent of the labor force unemployed and the number unemployed were taken from the U.S. Bureau of Census. The historical period under analysis (1890 to 1940) includes five depressions/ recessions (defined as unemployment above 8 percent), with unemployment ranging from 8.5 percent in 1908 to 24.9 percent in 1933. Other high points of unemployment occurred in 1894 (18.4 percent) and 1921 (11.9 percent). ${ }^{2}$ Because these five depressions/recessions varied in length as well as in rate of unemployment, and because the length of a recession may affect the level of hardship as well as the organizational capacity of the unemployed, we must consider the length of a recession in our analysis. Specifically, these five depressions/recessions ranged in length from one year (1908) to 11 years (1930 to 1940). ${ }^{3}$ We can assume that each consecutive year of high unemployment adds to the hardship of the unemployed. For example, historical reports tell us that local aid to the unem- 
ployed was used up if unemployment lasted longer than a few months (Feder; Garraty). Also, with more people out of work for longer periods of time there is a greater capacity to organize for social movement activity. Thus, recession years were coded one for the first year of 8 percent or more unemployment, two for the second consecutive year, three for the third, and so on.

Our data on protest by the unemployed (our dependent variables) come from the New York Times. We will not provide an extensive defense of the New York Times as a data source because such a defense has been provided by others (see Jenkins and Perrow; Paige; Snyder and Tilly; Stohl; Tilly et al.). Also, there have been two recent empirical examinations of the validity and reliability of data collection from major newspapers (see Danzger; Snyder and Kelly). This research has found the use of newspapers as data sources for protest events generally acceptable and more complete than any other source.

Research assistants examined the New York Times Index for newspaper articles about protest events from 1890 to 1940, then read the original articles and coded the necessary information. Only protest events by the unemployed themselves (including public assistance recipients) were coded. ${ }^{4} \mathrm{~A}$ total of 303 protest events were located, read, and coded.

To check the accuracy of the coding the authors randomly selected six years and followed the same coding procedures. ${ }^{5}$ As another means of checking the accuracy of our coding (and to obtain an essence of what was being reported in the New York Times), one of the authors selected key time periods and examined every page of the New York Times, reading articles related to our subject matter. ${ }^{6}$

It is important to note some specific limitations of our data source for protest events. As might be expected, studies (e.g., Snyder and Kelly) have shown that newspapers are somewhat selective in their coverage of collective violence and protest. Newspapers are more likely to print stories on bigger events, and events closer to the geographical area where the newspaper is published. Thus, our data are no doubt biased in these respects. But we have no reason to believe the Northeastern United States differed substantially from the rest of the country in protest by the unemployed.?

We checked the accuracy of our data source in two ways. First, we selected key time periods and examined every page of the San Francisco Chronicle for reports of protest. ${ }^{8}$ Both the New York Times and the San Francisco Chronicle included relatively small local events not found in the other newspaper, but the overall magnitude of protest was similar as reported in both newspapers. Second, we read major historical works and checked their reports of collective protest by the unemployed against our New York Times data (these works included Feder; Garraty; Goldman; Hofstader; Piven and Cloward, $a, b ;$ Schlesinger, $a, b, c)$. Our New York Times data were 
the most complete we found for the total time period examined, and our data generally conformed to the descriptions in the historical works. How: ever, we suggest caution in accepting our low estimate of the magnitude of protest for the early years we analyzed (discussed in more detail below). It seems safest to assume that we have at best a very conservative estimate of the magnitude of protest in these early years.

Generalized least squares, with the Cochrane-Orcutt method of correcting for autocorrelation effects, ${ }^{9}$ was the primary statistical technique used (Hibbs,b; Johnston; Kmenta; Ostrom). All variables were logged to reduce skewness. Logic suggests that some lagged relationship may exist between unemployment and protest. However, an analysis using lagged variables proved unproductive. Data for unemployment rates before World War II exist only for one-year intervals. Thus, if there is a lag between changes in the unemployment rates and protest, it is less than one year (at least for the period of history examined).

\section{Findings}

We first look at the simple relationship between the yearly number of protest events and the unemployment rate from 1890 to 1940 shown in Figure 1. As we do so, it is important to keep in mind that the Times no doubt gives a conservative estimate of the amount of protest, especially in the early years. As others have suggested (e.g., Snyder and Kelly), there is probably a threshold effect which leads newspapers to underreport events such as protest until they reach a certain level of intensity. With the high unemployment of the 1890s we find very little protest reported in the Times. But we do find at least some reports of protest with every period of over 8 percent unemployment between 1890 and 1940. More significant, we generally find increasing numbers of protesters involved in protest activities (not shown in Figure 1). For example, while our sources estimated about 500 protesters for 1894, this increased to 4,800 for 1908 and 3,500 for $1914 .^{10}$

By the 1930s the number of protests and protesters had increased dramatically. The increase in protest events is clear from Figure 1. The increase in the number of protesters in the very first year of the Great Depression is, however, even more dramatic. The year 1930 found over 100,000 protesters in the streets, the second highest for the total period. Of further note is the pattern for the latter years of the 1930s indicating that protest continued to go up as unemployment was going down. Two observations can be made on this pattern. First, although unemployment was going down, it was still very high. In addition, many of the aid programs introduced in 1933 and 1934 were being cut back or eliminated by 1935 to 1937. 


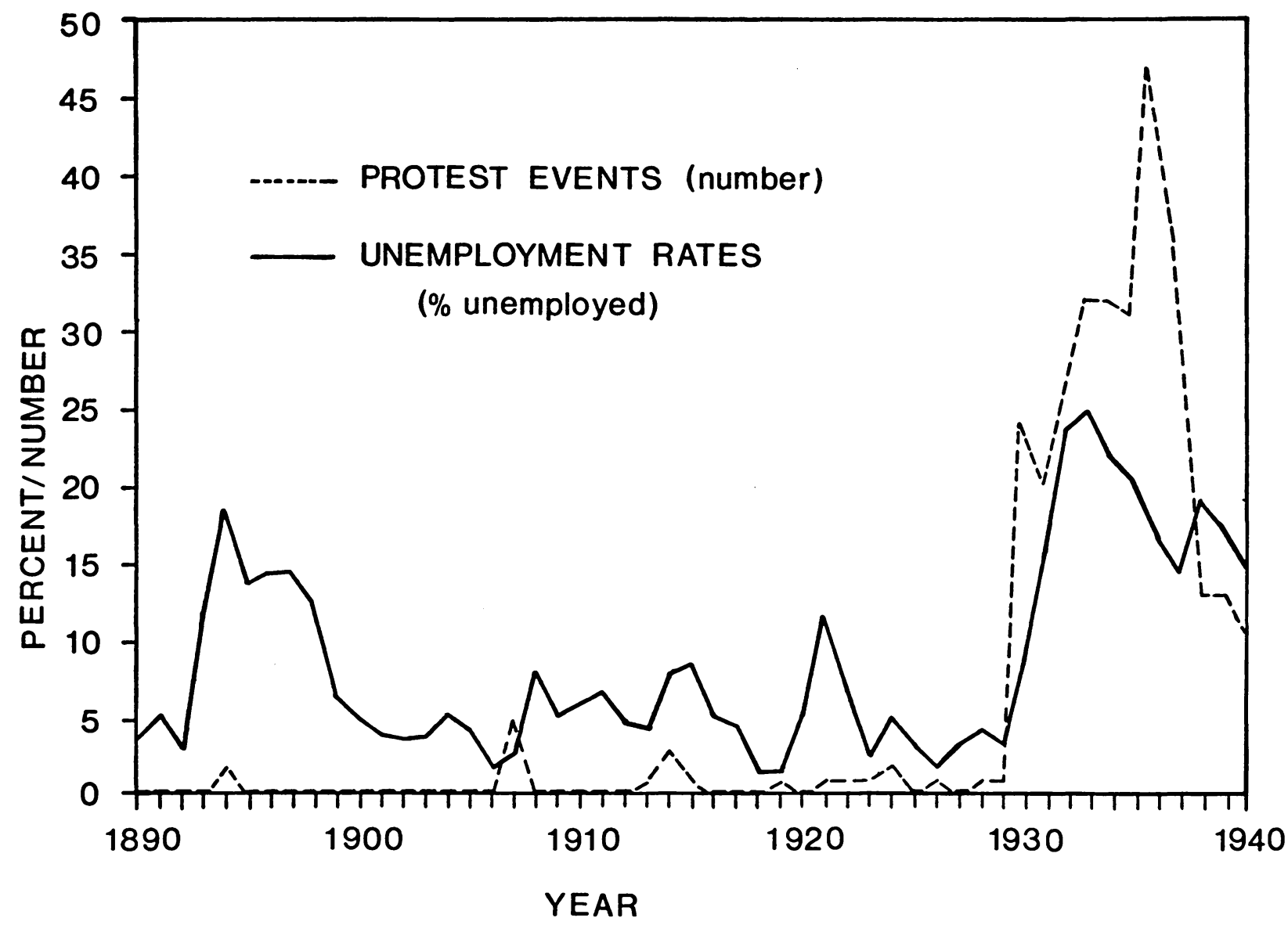

Figure 1. PROTESTS AND UNEMPLOYMENT RATES 
Historical accounts suggest that these cuts in aid were important in producing protest activity (Schlesinger, $a, b$ ).

Turning to our statistical analysis, Table 1 confirms what Figure 1 shows. Three measures of protest (number of protests, number of protesters, duration of protest events) are significantly related to our three indicators of hardship (percent unemployment, actual number of unemployed, and duration of depression) between 1891 and 1940. All of the betas for the 1891-1940 period range between .31 and .53 .

With massive protest and very high unemployment during the 1930s (see Figure 1), however, it can be suggested that our strong correlations between unemployment and protest are due primarily to the 1930s. Table 1 suggests this to be the case. The betas between protest and our indicators of hardship are strong for the period from 1919 to 1940, but there are few significant correlations for the period from 1891 through 1918.

\section{Discussion}

The primary purpose of this paper has been to show that group analysis is much more useful than event analysis in understanding social movements and political violence. Previous research using event analysis has treated a subject with a complex causal base in an overly simplistic manner. Using group analysis, we are able to focus on a particular issue or possible source of discontent, while excluding others, to find whether that issue is likely to produce collective violence and social movements. Equally important, using group analysis we can follow a particular group through history to understand changes that make social movements and collective violence more or less likely to occur.

With the example of protest by the unemployed from 1890 to 1940, group analysis has forced us to face some key questions. In what ways did the 1890s differ from the 1930s? There was massive unemployment in both time periods, but the level of protest differed significantly. Is it possible that a greater concentration of urban workers in the 1930s made organization more likely? In what way did the political environment of the 1890s differ from that of the 1930s? For example, we know that Franklin Roosevelt was more supportive of labor organization than any previous president. In other words, is it a matter of more social movement resources for the unemployed in the 1930s than in the 1890s? We believe this is the case, and that resource mobilization theory is needed for a full understanding of protest activity by the unemployed during this period. In this short research note, however, our primary point has been that by using group analysis we are able to examine these questions in a more precise manner. 
Table 1. HARDSHIP AND PROTEST (STANDARDIZED BETA COEFFICIENTS)

\begin{tabular}{|c|c|c|c|c|c|c|c|c|c|c|c|c|}
\hline & \multicolumn{3}{|c|}{ Number of Protests } & \multicolumn{3}{|c|}{ Number of Protesters } & \multicolumn{3}{|c|}{ Duration of Protests } & \multicolumn{3}{|c|}{ Number of Arrests } \\
\hline & $\begin{array}{l}1891- \\
1940\end{array}$ & $\begin{array}{l}1891- \\
1918\end{array}$ & $\begin{array}{l}1919- \\
1940\end{array}$ & $\begin{array}{l}1891- \\
1940\end{array}$ & $\begin{array}{l}1891- \\
1918\end{array}$ & $\begin{array}{l}1919- \\
1940\end{array}$ & $\begin{array}{l}1891- \\
1940\end{array}$ & $\begin{array}{l}1891- \\
1918\end{array}$ & $\begin{array}{l}1919- \\
1940\end{array}$ & $\begin{array}{l}1891- \\
1940\end{array}$ & $\begin{array}{l}1891- \\
1918\end{array}$ & $\begin{array}{l}1919- \\
1940\end{array}$ \\
\hline \multicolumn{13}{|l|}{ Table A } \\
\hline \multirow{2}{*}{\multicolumn{13}{|c|}{$\begin{array}{l}\text { Unemployment } \\
\text { rate } \\
\text { Rho } \\
\text { Durbin-Watson } \\
\text { Table B } \\
\end{array}$}} \\
\hline & & & & & & & & & & & & \\
\hline $\begin{array}{l}\text { Number of } \\
\text { unemployed } \\
\text { Rho } \\
\text { Durbin-Watson }\end{array}$ & $\begin{array}{l}.44 \div 2 \times x \\
.80 \\
2.44\end{array}$ & $\begin{array}{l}.40 \% \\
-.13 \\
1.93\end{array}$ & $\begin{array}{l}.45 * \\
.67 \\
2.28\end{array}$ & $\begin{array}{l}.53 \div \% 4 \\
.48 \\
2.37\end{array}$ & $\begin{array}{l}.41 \% \\
.31 \\
1.91\end{array}$ & $\begin{array}{l}.84 \div \div * \% \\
-.19 \\
2.22\end{array}$ & $\begin{array}{l}.43 * * \\
.81 \\
2.45\end{array}$ & $\begin{array}{l}.40 * \\
.16 \\
1.92\end{array}$ & $\begin{array}{l}.43 * \\
.70 \\
2.38\end{array}$ & $\begin{array}{r}.27 \\
.83 \\
2.94\end{array}$ & $\begin{array}{r}.29 \\
-.15 \\
2.04\end{array}$ & $\begin{array}{l}.67 \div \div * \\
.24 \\
2.61\end{array}$ \\
\hline Table C & & & & & & & & & & & & \\
\hline $\begin{array}{l}\text { Duration of } \\
\text { depression } \\
\text { Rho } \\
\text { Durbin-Watson }\end{array}$ & $\begin{array}{l}.37 \% \\
.84 \\
2.49\end{array}$ & $\begin{array}{r}.13 \\
.27 \\
2.15\end{array}$ & $\begin{array}{l}.49 \div \\
.79 \\
2.46\end{array}$ & $\begin{array}{l}.38 \div * x \\
.66 \\
2.44\end{array}$ & $\begin{array}{r}.22 \\
.47 \\
2.09\end{array}$ & $\begin{array}{r}.39 \\
.61 \\
2.82\end{array}$ & $\begin{array}{l}.31 \% \\
.86 \\
2.49\end{array}$ & $\begin{array}{r}.11 \\
.29 \\
2.12\end{array}$ & $\begin{array}{r}.40 \\
.82 \\
2.46\end{array}$ & $\begin{array}{r}.24 \\
.83 \\
2.93\end{array}$ & $\begin{array}{r}.10 \\
-.03 \\
2.17\end{array}$ & $\begin{array}{l}.71 \div \pm * \\
.10 \\
2.19\end{array}$ \\
\hline
\end{tabular}




\section{4 / Social Forces Volume 64:4, June 1986}

\section{Notes}

1. We coded protest events only when a news article indicated that the unemployed or welfare recipients were the primary participants. In a case where employed workers went on strike or marched in sympathy for the unemployed, for example, the protest event was not included in our data. It is also worth noting that we have coded protest events rather than collective violence per se, though most cases of protest by the unemployed reported in the New York Times would fit Snyder and Tilly's definition of collective violence. For coding purposes, our definition of protest by the unemployed was a group of 10 or more individuals who were unemployed coming together for the purpose of demonstrating or calling attention to their problems of unemployment.

2. The high points of unemployment in these five recessions/depressions are as follows: 1894-18.4 percent; $1908-8.5$ percent; $1915-9.7$ percent; $1921-11.9$ percent; 1933-24.9 percent (U.S. Bureau of Census).

3. The consecutive years of 8 percent or more unemployment are as follows: 1893 to 1898 (6 years), 1908 (1 year), 1914 to 1915 (2 years), 1921 (1 year), 1930 to 1940 (11 years).

4. This coding procedure excluded primarily strikes or other collective action by the employed. Some of these events were on behalf of the unemployed, but it was difficult to separate out the most important issue behind a strike. Specifically, following standard procedures (see Paige), under protest by the unemployed we coded the number of people involved, location, target and goals of the action, and number arrested, injured and killed. While 67 percent of the protest events lasted one day or less, especially in the 1930s many protest events involved lengthy marches and occupations of public sites, especially in Washington, D.C.

5. We selected 1908, 1913, 1920, 1921, 1922, and 1929 for validity checks. The overall agreement rate was 87 percent.

6. This method was employed to make sure the New York Times Index was accurate and employed accurately by our coders. Reading the entire Index for the total time period was impossible, but we found some key index headings most likely to contain the information required (especially "unemployment"). Most of the years and months selected for this additional analysis were selected because they were election years with high unemployment, but with very few protest events located in our primary coding procedure. The dates examined were January to March 1894, August to November 1894, August to November 1896, and August to November 1908. This method strongly confirmed the validity of our coding procedures.

7. One limitation of our data collection method was the underreporting of rural protest. The historical works on the 1930s suggest that protest in rural areas was significant, but only 2 percent of our protest events were located in rural areas. Also of note, 74 percent of our protest events were on the East Coast and 91 percent in large cities.

8. The selection of time periods to reexamine in the San Francisco Chronicle followed the selection described in note 6 above.

9. The Cochrane-Orcutt method was chosen over the first differences method because Rho (or $P$ ) does not equal 1.0, which is an assumption of the first differences method (see Kmenta).

10. Figure 1 presents the number of protest events reported in the Times rather than the number of protesters involved. The estimated numbers of protesters involved in key years are as follows: $1894-500 ; 1908-4,800 ; 1914-3,500 ; 1922-450 ; 1930-102,500 ; 1931-10,800$; $1932-63,700 ; 1933-73,450 ; 1934-19,900 ; 1935-41,300 ; 1936-29,400 ; 1937-49,400 ; 1938-$ 39,$250 ; 1939-113,900 ; 1940-670$.

These figures show the rapid jump in protest in 1930 more clearly (to 102,500 protesters), as well as the extensiveness of protest in some earlier years. 


\section{Unemployment and Protest / 1055}

\section{References}

Carroll, M. 1975. "Revitalization Movements and Social Structure: Some Quantitative Tests." American Sociological Review 40:389-401.

Champagne, D. 1983. "Social Structure, Revitalization Movements and State Building: Social Change in Four Native American Societies." American Sociological Review 48:754-63.

Danzger, M. H. 1975. "Validating Conflict Data." American Sociological Review 40:570-84.

Feder, Leah Hannah. 1936. Unemployment Relief in Periods of Depression. Russell Sage Foundation.

Garraty, John. 1978. Unemployment in History: Economic Thought and Public Policy. Harper \& Row.

Goldman, Eric F. 1953. Rendezvous with Destiny. Knopf.

Gurr, Ted. 1970. Why Men Rebel. Princeton University Press.

Hibbs, Douglas A., Jr. a:1974. Industrial Conflict in Advanced Industrial Societies. Center for Political Studies, M.I.T.

. b:1974. "Problems of Statistical Estimation and Causal Inference in Time Series Regression Models." In Herbert Costner (ed)., Sociological Methodology, 1974-1975. JosseyBass.

Hofstadter, Richard. 1955. The Age of Reform: From Bryan to FDR. Knopf.

Isaac, L., E. Mutran, and S. Stryker. 1980. "Political Protest Orientations Among Black and White Adults." American Sociological Review 45:191-213.

Jenkins, J. C., and C. Perrow. 1977. "Insurgency of the Powerless: Farm Worker Movements, 1946-1972." American Sociological Review 42:249-67.

Johnston, John. 1972. Econometric Methods. 2d ed. McGraw-Hill.

Kerbo, H. 1982. "Movements of Crisis and Movements of 'Affluence': A' Critique of Deprivation and Resource Mobilization Theories of Social Movements." Journal of Conflict Resolution 26:645-63.

Kmenta, Jan. 1971. Elements of Econometrics. Macmillan.

McCarthy, J., and M. Zald. 1977. "Resource Mobilization and Social Movements: A Partial Theory." American Journal of Sociology 82:1212-41.

Ostrom, Charles W., Jr. 1978. Time Series Analyses: Regression Techniques. Sage.

Page, A., and D. A. Clelland. 1978. "The Kahawha County Textbook Controversy: A Study of the Politics of Lifestyle Concern." Social Forces 57:265-71.

Paige, Jeffrey. 1975. Agrarian Revolution. Free Press.

Piven, Frances Fox, and Richard Cloward. a:1971. Regulating the Poor: The Functions of Public Welfare. Pantheon. . b:1977. Poor People's Movements: When They Succeed, Why They Fail. Pantheon.

Schlesinger, Arthur M., Jr. a:1957. The Age of Roosevelt I: The Crisis of the Old Order, 1919-1933. Houghton Mifflin.

b:1959. The Age of Roosevelt II: The Coming of the New Deal. Houghton Mifflin.

c:1960. The Age of Roosevelt III: The Politics of Upheaval. Houghton Mifflin.

Shorter, Edward, and Charles Tilly. 1974. Strikes in France, 1830-1968. Cambridge University Press.

Skeels, J. W. 1971. "Measures of U.S. Strike Activity." Industrial and Labor Relations Review 24:515-25.

Snyder, D. 1975. "Institutional Setting and Industrial Conflict: Comparative Analysis of France, Italy, and the United States." American Sociological Review 40:259-78.

Snyder, D., and W. Kelly. 1977. "Conflict Intensity, Media Sensitivity and the Validity of Newspaper Data." American Sociological Review 42:105-23.

Snyder, D., and C. Tilly. 1972. "Hardship and Collective Violence in France, 1830 to 1960." American Sociological Review 37:520-32.

Stohl, Michael. 1976. War and Domestic Political Violence: The American Capacity for Repression and Reaction. Sage. 
1056 / Social Forces Volume 64:4, June 1986

Thornton, R. 1981. "Demographic Antecedents of a Revitalization Movement: Population Change, Population Size, and the 1890 Ghost Dance." American Sociological Review 46:8896.

Tilly, Charles, Louise Tilly, and Richard Tilly. 1975. The Rebellious Century. Harvard University Press.

United States Bureau of the Census. 1975. Historical Statistics of the United States: Colonial Times to 1970 , Parts 1 \& 2 . GPO.

Useem, B. 1980. "Solidarity Model, Breakdown Model, and the Boston Anti-busing Movement." American Sociological Review 45:357-69.

Walsh, E. J., and R. H. Warland. 1983. "Social Movement Involvement in the Wake of a Nuclear Accident: Activists and Free Riders in the TMI Area." American Sociological Review 48:764-80. 